\title{
PKM PENGAYAAN MATERI OLIMPIADE MATEMATIKA UNTUK GURU SD AL FATH DAN SD JAMBI ISLAMIC SCHOOL KOTA JAMBI PROVINSI JAMBI
}

\author{
Rohati ${ }^{*}$, Feri Tiona Pasaribu ${ }^{1}$, Diah Kumalasari ${ }^{2}$ \\ ${ }^{1}$ Program Studi Pendidikan Matematika, Fakultas Keguruan dan Ilmu Pendidikan, Universitas Jambi, Jambi, \\ Indonesia \\ ${ }^{2}$ Program Studi Teknik Sipil, Fakultas Teknik, Universitas Jambi, Jambi, Indonesia \\ *Penulis korespondesi: rohati.fkip@unja.ac.id
}

\begin{abstract}
Abstrak
Olimpiade merupakan ajang yang sangat bagus untuk mengasah kemampuan matematika seseorang pelajar. Sebelum guru membantu siswa mempelajari soal-soal olimpiade, terlebih dahulu guru harus mampu menguasai dengan baik soal soal jenis olimpiade di SD. Kenyataan di lapangan menunjukkan bahwa masih banyak guru yang belum memiliki pemahaman yang baik tentang soal-soal matematika yang diujikan pada olimpiade matematika SD. Hal ini terjadi di SD Alam Al-Fath dan SDIT JISc Kota Jambi.Tujuan yang akan dicapai dari pengabdian ini adalah memberikan pengayaan dan workshop tentang olimpiade matematika bagi guru SD dalam membuat dan menyelesaikan soal-soal bertaraf olimpiade. Selanjutnya dengan pengabdian ini akan menghasilkan modul pengayaan materi-materi olimpiade matematika SD.Adapun khalayak sasaran adalah guru-guru di SD Alam Al-Fath dan SDIT JISc Kota Jambi. Untuk mengukur keberhasilan pengabdian akan dilakukan evaluasi dengan menggunakan instrumen berupa angket dan tes. Dari hasil tes diperoleh peningkatan dari pretest ke posttes sebesar $30,17 \%$. Berdasarkan hasil respon guru dengan pemberian angket setelah mengikuti kegiatan pengabdian kemitraan masyarakat ini guru-guru di SD tersebut bisa memiliki pemahaman yang baik tentang soal-soal olimpiade matematika tingkat SD dan memberikan respon yang positif terhadap kegiatan pelatihan dan mampu membina, memotivasi dan meningkatkan minat siswa agar dapat mengikuti ajang olimpiade matematika, serta membelajarkan siswa dengan baik dan efektif.
\end{abstract}

Kata kunci : Pengayaan, Materi Olimpiade, Matematika.

\begin{abstract}
The Olympics is a great place to improve student's math skills. Before the teacher helps the students to learn Olympic questions, teacher must be able to master the questions about the types of Olympics in elementary school. The reality in the field shows that there are still many teachers who do not have a good understanding of the mathematics that were tested for elementary mathematics olympiad. This happened in SD Alam Al-Fath and SDIT JISc Jambi City. The aim to be achieved from this service was to provide enrichment and workshops on mathematics olympiad for elementary teachers in making and completing Olympic-level questions. Furthermore, with this dedication, it will produce an enrichment module for elementary mathematics olympiad materials. The target audiences are teachers at SD Alam Al-Fath and SDIT JISc Jambi City. To measure the success of dedication, an evaluation will be conducted using instruments such as questionnaires and tests. From the test results obtained that there is an enhacement from pretest to posttest by $30.17 \%$. Based on the results of the teacher's response by answered the questionnaires after participating in this community partnership service, the teachers at the elementary school could have a good understanding of elementary school mathematics olympiad questions and provide a positive response to training activities and be able to foster, motivate and increase the students' interest to follow the mathematics Olympiad event, and to teach students well and effectively.
\end{abstract}

Keywords: Elementary School Teacher, Olympic Materials, Mathematics. 


\section{PENDAHULUAN}

Era globalisasi, teknologi tidak bisa dipungkiri perkembangannya yang semakin pesat. Secara tidak langsung kita harus meningkatkan kualitas sumber daya manusia di berbagai bidang. Dalam meningkatkan sumber daya manusia, salah satunya adalah dengan meningkatkan kemampuan dalam bidang pendidikan.

Selama ini pemerintah sudah banyak memberikan program dalam peningkatan mutu pendidikan, yaitu dengan adanya ruang dan kesempatan dalam mengikuti kompetisi yang dilakukan dalam bidang pendidikan, misalnya sejenis olimpiade baik nasional maupun skala international. Diharapkan banyak siswa berlombalomba mengikuti kontes intelektual bergengsi ini (Kuswidi \& Hart., 2017). Oleh sebab itu, olimpiade untuk bidang studi matematika, masih sangat perlu disosialisasikan kepada siswa, orang tua siswa, guru dan pengawas Dinas Pendidikan. Sehingga tujuan olimpiade belum dapat diwujudkan secara optimal. Selain itu, minat sumber daya manusia dalam hal ini siswa, untuk mengikuti setiap ajang kompetisi tidak sesuai dengan yang diharapkan.Salah satu faktor kurangnya minat siswa mengikuti setiap kompetisi yaitu kurangnya pemahaman guru khususnya guru matematika, baik tentang seluk beluk olimpiade maupun kemampuan guru dalam mengembangkan soal-soal yang bertaraf olimpiade dalam pembelajaran di dalam kelas bahkan kemampuan guru dalam menyelesaikan soal-soal yang bertaraf olimpiade juga masih kurang.

Sekolah Dasar merupakan satuan pendidikan tingkat dasar merupakan pondasi untuk tingkat pendidikan selanjutnya yang lebih tinggi (Suarsana, 2017). Pelaksanaan Olimpiade Matematika SD mempunyai tujuan yaitu tujuan umum dan tujuan khusus. Secara umum tujuan olimpiade matematika SD adalah untuk meningkatkan mutu pendidikan matematika secara komprehensif melalui menumbuhkembangan budaya belajar, kreatifitas dan motivasi meraih juara melalui kompetisi yang sehat serta menjunjung nilai-nilai sportifitas. Hal ini dapat mendukung pengembangan pola pikir dan daya nalar (Jana, 2017).

Berdasarkan tujuan olimpiade matematika tersebut, seharusnya guru-guru bidang studi matematika di sekolah dapat membina dan mempersiapkan siswasiswa mereka untuk berkompetisi dalam olimpiade matematika, mulai dari tingkat kabupaten/kota, tingkat propinsi, tingkat nasional, bahkan sampai tingkat internasional. Persiapan untuk mengikuti olimpiade tidak mungkin dilakukan di kelas umum. Untuk itu diperlukan persiapan khusus yang mengarahkan siswa untuk menyelesaikan soal-soal olimpiade (Makur dkk, 2018). Dalam pembinaan olimpiade peran guru sebagai Pembina olimpiade matematika di sekolah yaitu menanamkan kemampuan dasar matematika, mengidentifikasi siswa yang potensial dalam matematika dan memelihara potensi siswa tersebut, serta harus mempunyai sikap untuk lebih memposisikan diri sebagai pembina atau pelatih. Guru juga harus bisa mengarahkan siswa agar bisa belajar memecahkan masalah (Mairing dkk, 2011). Hal ini akan membuat siswa bangga dan gembira ketika dia mampu memecahkan masalah yang dihadapnya. (Trisnowali, 2015).

SD Al Fath dan SD Jambi Islamic School merupakan sekolah yang berdomisili di wilayah kota Jambi. Berdasarkan hasil survei di lapangan menunjukkan bahwa kedua sekolah sama sekali belum ada tim pembinaan untuk olimpiade khususnya olimpiade matematika. Kedua sekolah masih terpusat pada sistem pembelajaran yang baik namun sosialisasi tentang seluk beluk olimpiade belum ada dimanfaatkan apalagi sekolah tersebut memiliki SDM yang baik.Jika ada informasi ajang kompetisi, sekolah masih mengabaikan kesempatan tersebut.

Berdasarkan studi lapangan melalui wawancara yang dilakukan tim pengabdian dengan Kepala Sekolah, kedua sekolah tersebut juga belum pernah mengikuti kegiatan olimpiade matematika sejenis. Hal ini disebabkan selain kurangnya sosialisasi olimpiade kepada siswa dan wali murid, kurangnya pembinaan guru olimpiade juga menjadi faktor utama dalam membina siswa aktif dalam mengikuti olimpiade. Untuk sukses berjalan menuju ke olimpiade matematika, siswa harus memiliki ketekunan, pemahaman konsep, kreativitas, wawasan yang luas dan komunikatif (Kusuma, 2010). Hasil penelitian yang dilakukan Rohim \& Sari (2019) menunjukkan bahwa siswa yang terbiasa mengikuti olimpiade matematika bisa menyajikan solusi dengan lebih terstruktur.

Berdasarkan uraian di atas, penulis melakukan kegiatan pengabdian kemitraan masyarakat bagi guru guru di sekolah tersebut. Setelah mengikuti kegiatan ini diharapkan guru bisa memiliki wawasan dan pengalaman serta pemahaman yang baik tentang seluk beluk olimpiade baik penyelesaian soal-soal olimpiade matematika tingkat SD maupun kreativitas guru untuk merancang soal-soal yang setaraf olimpiade. Selain itu, mampu membina, memotivasi dan meningkatkan minat siswa agar dapat mengikuti ajang olimpiade matematika sehingga menjadi lebih kreatif dan inovatif, serta membelajarkan siswa dengan baik dan efektif (Suryawan dkk, 2017). Kegiatan ini juga menghasilkan suatu modul tentang materi pengayaan olimpiade matematika untuk guru SD. Dengan modul tersebut diharapkan membuat guru bisa lebih mudah memahami konsep-konsep dari materi olimpiade matematika tersebut (Mardiyan dkk, 2016).

\section{METODE PELAKSANAAN}

Metode pelaksanaan kegiatan dilakukan ke dalam beberapa metode, yaitu:

\section{Persiapan}

Pada tahap persiapan, terdapat beberapa kegiatan, diataranya: (a) melakukan rapat koordinasi dengan Sekolah Mitra (SD Al Fath dan SD Jambi IslamicSchool), (b) Sosialisasi program pengayaan 
materi olimpiade matematika SD pada dua sekolah mitra (khalayak sasaran), (c) memberikan penyuluhan tentang pelaksanaan olimpiade matematika SD termasuk teknik teknik untuk menjadi juara olimpiade matematika.

\section{Pelaksanaan}

Pada tahap pelaksanaan, terdapat beberapa kegiatan, diantaranya: (a) dilakukan kegiatan sosialisasi program pengayaan materi olimpiade matematika SD, (b) penyuluhan tentang pelaksanaan olimpiade matematika SD termasuk teknik untuk menjadi juata olimpiade matematika, (c) uji coba membahas soal-soal olimpiade matematika SD mulai dari soal tingkat sekolah, tingkat kabupaten/kota, tingkat propinsi sampai soal-soal tingkat nasional serta internasional.

\section{Observasi dan Evaluasi}

Evaluasi pelaksanaan kegiatan pengabdian ini dirancang sebagai berikut:

a. Evaluasi awal berupa pre-test yang berguna untuk menggali kemampuan awal sebagai pijakan untuk menentukan materi-materi mana yang harus diberikan.

b. Evaluasi akhir berupa post-test yang berguna untuk melihat tingkat kemajuan setelah peserta diberikan pengayaan maupun pelatihan.

c. Evaluasi terhadap pelaksanaan dilakukan dengan memberikan angket, yang akan mengukur tingkat keberhasilan dari pelaksanaan kegiatan ini atau melihat sejauh mana pemahaman guru-guru tentang materi olimpiade dan tes yang digunakan untuk melihat kemampuan guru dalam menyelesaikan soal-soal olimpiade.

\section{Tidak Lanjut (Revisi)}

Tahap revisi dilakukan sebagai tindak lanjut perbaikan mengevaluasi kegiatan pelatihan yang telah dilaksanakan.Hal ini dilakukan semata-mata untuk mendapatkan umpan balik dan mengetahui berbagai kekurangan kegiatan pelatihan yang telah dilaksanakan, selanjutnya dijadikan sebagai dasar menetapkan rekomendasi keberlangsungan program pelatihan yang relevan.

\subsection{Metode Pendekatan}

Metode pendekatan yang digunakan dalam kegiatan ini disesuaikan dengan permasalahan dan terget capaian setiap kegiatan. Beberapa metode yang dapat digunakan dalam kegiatan ini yaitu: pelatihan, pendampingan, ujicoba, wawancara, catatan lapangan dan observasi. Setiap metode diaplikasikan berdasarkan tujuan kegiatan yang ingin dicapai.Untuk lebih jelasnya, dapat dilihat pada tabel berikut.

Tabel 1.Metode Pendekatan Pelaksanaan Kegiatan

\begin{tabular}{clll}
\hline No. & \multicolumn{1}{c}{ Kegiatan } & \multicolumn{1}{c}{ JenisLuaran } & \multicolumn{1}{c}{ Metode } \\
\hline 1. & Sosialisasi & Modulpengayaa & Pelatihan, \\
& program & nmateriolimpia & Observasi, \\
pengayaan & dematematika & CatatanLapa \\
materi & SD & ngan \\
\hline
\end{tabular}

\begin{tabular}{|c|c|c|c|}
\hline & $\begin{array}{l}\text { olimpiade } \\
\text { matematika } \\
\text { SD }\end{array}$ & & \\
\hline 2. & $\begin{array}{l}\text { Penyuluhan } \\
\text { tentangpelak } \\
\text { sanan } \\
\text { olimpiade } \\
\text { matematika } \\
\text { SD termasuk } \\
\text { teknik teknik } \\
\text { atau strategi } \\
\text { pembinaan } \\
\text { untuk } \\
\text { menjadi } \\
\text { juaraolimpia } \\
\text { de } \\
\text { matematika. }\end{array}$ & $\begin{array}{l}\text { Panduan } \\
\text { teknik-teknik } \\
\text { dalam } \\
\text { menyelesaikan } \\
\text { soal olimpiade }\end{array}$ & $\begin{array}{l}\text { Pelatihan, } \\
\text { Pendamping } \\
\text { an, } \\
\text { Observasi, } \\
\text { Wawancara }\end{array}$ \\
\hline 3. & $\begin{array}{l}\text { Uji coba/ } \\
\text { simulasi } \\
\text { pembahasan } \\
\text { soal-soal } \\
\text { olimpiade } \\
\text { matematika } \\
\text { SD }\end{array}$ & $\begin{array}{l}\text { Guru dan } \\
\text { siswaSD Alam } \\
\text { Al-Fathdan } \\
\text { SD Jambi } \\
\text { Islamic School } \\
\text { (JISc)dalamm } \\
\text { enyelesaikans } \\
\text { oaldalambentu } \\
\text { kCD }\end{array}$ & $\begin{array}{l}\text { Pelatihan, } \\
\text { Pendamping } \\
\text { an, Simulasi, } \\
\text { Observasi, } \\
\text { Wawancara, } \\
\text { CacatanLapa } \\
\text { ngan }\end{array}$ \\
\hline
\end{tabular}

\section{HASIL DAN PEMBAHASAN}

\subsection{Hasil Kegiatan}

Hasil kegiatan pengabdian dilakukan dalam beberapa kegiatan, antara lain: persiapan, pelaksanaan, evaluasi dan refleksi, dan tindak lanjut(revisi). Lebih jelas dapat dijabarkan sebagai berikut:

\section{Tahap Persiapan}

Pada tahap persiapan, dilakukan beberapa kegiatan, yaitu: membangun komitmen bersama dengan mitra melalui nota kesepakatan, menyiapkan modul pengayaan materi olimpiade matematika SD, contoh soal-soal olimpiade matematika SD, panduan teknikteknik menyelesaikan soal olimpiade matematika SD, dan menyiapkan sarana dan prasarana selama kegiatan dilaksanakan seperti: infocus Dan loudspeaker.

\section{Pelaksanaan Kegiatan}

Kegiatan pengabdian dilaksanakan pada bulan April sampai Juli di SD Alam Al-Fath dan SD Jambi Islamic School (JISc). Pada tahap pelaksanaan, dilakukan tiga tahap kegiatan, yaitu: Sosialisasi program pengayaan materi olimpiade matematika SD, Penyuluhan tentang pelaksanan olimpiade matematika SD termasuk teknik teknik untuk menjadi juara olimpiade matematika, Uji coba pembahasansoal-soal olimpiade matematika SD. Secara singkat langkah kegiatan yang dilakukan adalah sebagai berikut:

- Memberikan sosialisasi tentang pelaksanaan kegiatan pengayaan olimpiade.

- Sebelum memulai kegiatan, peserta pelatihan diberikan tes awal, dengan kualitas soal setara dengan olimpiade matematika yang telah disusun oleh tim. 
- Dari hasil tes tersebut, dilakukananalisauntuk melihat materi mana yang harus diberikan secara intensive.

- Kemudian dilakukan kegiatan pelatihan pengayaan materi-materi olimpiade.

- Setelah kegiatan pelatihan selesai makan akan dilanjutkan dengan kegiatan ujicoba atau simulasi pengerjaan soal olimpiade.

- Terakhir akan dilakukan post test dimana untuk megukur keberhasilan para peserta.

- Pada tahap evaluasi kegiatan akan diberikan angket kepada guru dan siswa.

Dari langkah-langkah kegiatan diatas akan dijabarkan lebih rinci sebagai berikut:

\section{a. Pemberian tes awal/pre test}

Pemberian pretest diberikan kepada peserta di kedua sekolah. Namun hasil analisa akan dilakukan secara bersamaan sehingga hasilnya akan dijadikan bahan pelatihan di kedua sekolah tersebut. Soal yang diberikan pada saat pre test berjumlah 15 soal yang tersusun dari tiga tipe soal yaitu uraian, isian dan eksplorasi. Soal yang disusun setara dengan soal olimpiade matematika SD. Hasil yang diperoleh dari hasil pre test menunjukkan bahwa kemampuan guru dalam menjawab soal secara acak hanya $47,72 \%$ yang menjawab benar. Selain itu peserta mengalami kesulitan dalam menyelesaikan masalah masalah eksplorasi, yang memang sering kali menjadi kendala bagi guru dalam membelajarkan kepada siswa. Walaupun pada materi lain dan tipe soal yang lain, guru banyak yang mengalami kendala dalam waktu dalam menyelesaikan soal dengan cepat dan tepat. Dari hasil tersebut, akan dijadikan dasar atau acuan bagi tim untuk memberikan pelatihan pada materi yang paling dibutuhkan peserta.

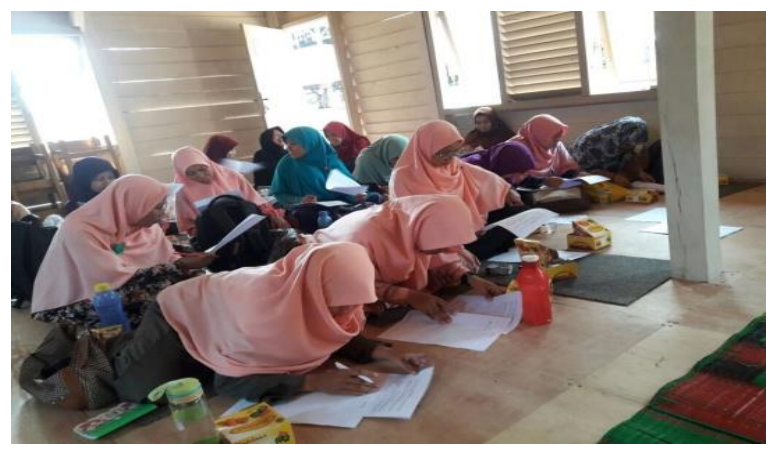

Gambar 1. Para guru sedang mengerjakan soal pretest.

\section{b. Sosialisasi program pengayaan materi olimpiade matematika SD}

Pada saat kegiatan pelatihan dilaksanakan diperoleh informasi bahwa perhatian para guru peserta kegiatan pengayaan materi olimpiade matematika sangat baik terhadap jalannya kegiatan. Hal ini ditandai dengan rasa antusias mereka pada saat pelatihan. Pertanyaan yang disampaikan nara sumber direspon dengan baik walaupun tidak semua pertanyaan dijawab dengan jawaban bernilai benar. Para guru juga semangat mengikuti pelatihan walaupun mereka memiliki background bidang keilmuan yang bukan matematika.

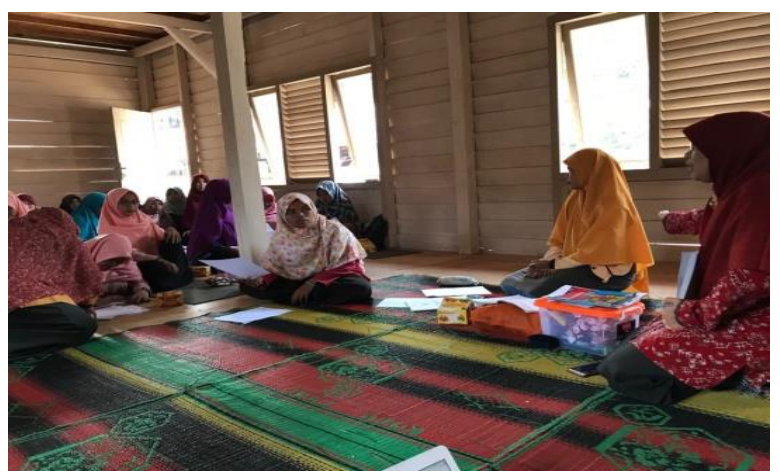

Gambar 2. Sosialisasi kegiatan di SD Alam Al-Fath Kota Jambi.

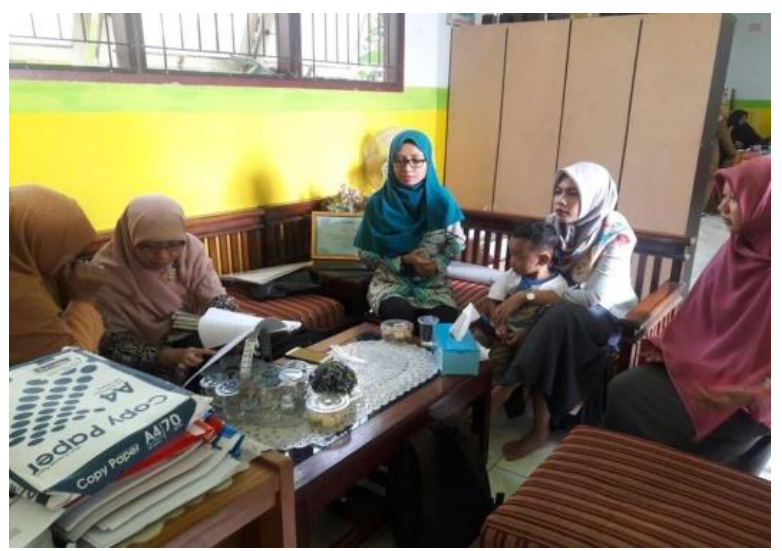

Gambar 3.Sosialisasi di SD Jambi Islamic School Kota Jambi.

Pada pengayaan materi olimpiade ini diambil kisi-kisi soal pengayaan materi olimpiade matematika memiliki komposisi sebagai berikut :

1. Soal isian singkat.

2. Soal uraian.

3. Soal eksplorasi. (Wibowo, 2015).

Selain bentuk soal yang dipaparkan, soal olimpiade yang diberikan juga memuat materi Bilangan, Aljabar, Geometri dan Statistika.

Berikut akan disajikan beberapa contoh soal olimpiade dari masing-masing komposisi yang diberikan pada saat pre test:

1. Soal isian singkat

Sebanyak 31 batang korek api tepat dapat digunakan untuk membentuk persegi panjang berukuran $1 \times 10$ sebagai berikut.

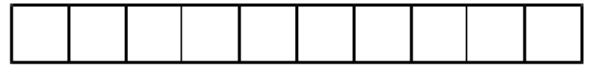

Sebanyak 52 batang korek api tepat dapat digunakan untuk membentuk persegi panjang dengan ukuran 2 $\times 10$

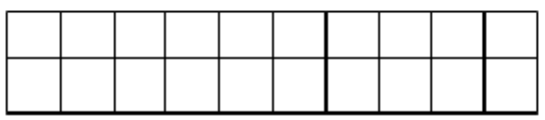

Banyaknya batang korek api yang tepat dapat digunakan untuk membentuk persegi panjang berukuran $2014 \times 10$ adalah $\ldots$. 


\section{Soal uraian}

Gambar di samping ini menunjukkan bahwa ADB merupakansetengah lingkaran dengan pusat di $\mathrm{E}$ dan $\mathrm{AB}=14 \mathrm{~cm}$. Jika $\angle \mathrm{BAD}=30 \circ$ dan busur $\mathrm{BC}$ merupakan bagian lingkaran dengan pusat $\mathrm{A}$. Tentukan keliling daerah yang diarsir. Gunakan $\pi=$ $\frac{22}{7}$.

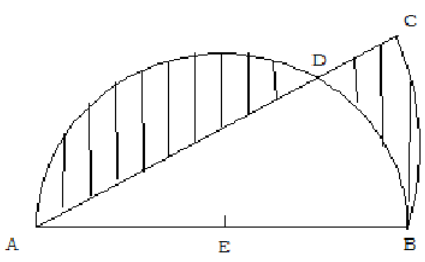

\section{Soal eksplorasi}

Dari sembarang bilangan 2-angka dapat dibentuk bilangan lain dengan cara mengalikan angka-angka pembentuknya. Proses tersebut dapat dilakukan berulang sampai hasilnya bilangan 1-angka. Sebagai contoh, seperti terlihat pada tabel, bilangan 87 berhenti di angka 0 , bilangan 26 berhenti pada angka 2, dan bilangan 12 berhenti pada angka 2 .

\begin{tabular}{|l|l|l|l|}
\hline Bilangan 2-angka & Langkah 1 & Langkah 2 & Langkah 3 \\
87 & $8 \times 7=56$ & $5 \times 6=30$ & $3 \times 0=0$ \\
26 & $2 \times 6=12$ & $1 \times 2=2$ & \\
12 & $1 \times 2=2$ & & \\
\hline
\end{tabular}

Tentukan semua bilangan 2-angka yang berhenti pada bilangan 8 .

Pada kegiatan pelatihan diberikan pembahasan soal-soal pre-test terlebih dahulu, agar peserta mengetahui kekurangan dan kesalahan merekadalam menyelesaikan soal-soal olimpiade dengan tepat dan cepat. Selain itu kegiatan pelatihan lebih difokuskan kepada pembahasan soal tentang materi eksplorasi karena materi ini pada umumnya memiliki tingkat kesulitan yang paling tinggi. Bahkan pada setiap peyelenggaraan kegiatan olimpiade, sesi eksplorasi diberikan pada hari terpisah dan mendapatkan porsi nilai yang paling tinggi. Sehingga tidak heran jika guru-gurunya pun mendapat kesulitan untuk materi ini yang akan berdampak pada siswa yang jarang mendapatkan soal eksplorasi.

\section{c. Penyuluhan tentang pelaksanan olimpiade matematika SD termasuk teknik teknik atau strategi pembinaan}

Penyampaian strategi pembinaan olimpiade Matematika sangat penting, sebab olimpiade Matematika merupakan ajang kompetisi. Soal olimpiade merupakan soal tidak rutin dan bersifat high order thingking skill (HOTS), sehingga dalam pengerjaannya diperlukan strategi yang khusus.

Beberapa gambar kegiatan yang dilakukan oleh tim pengabdian sebagai berikut:

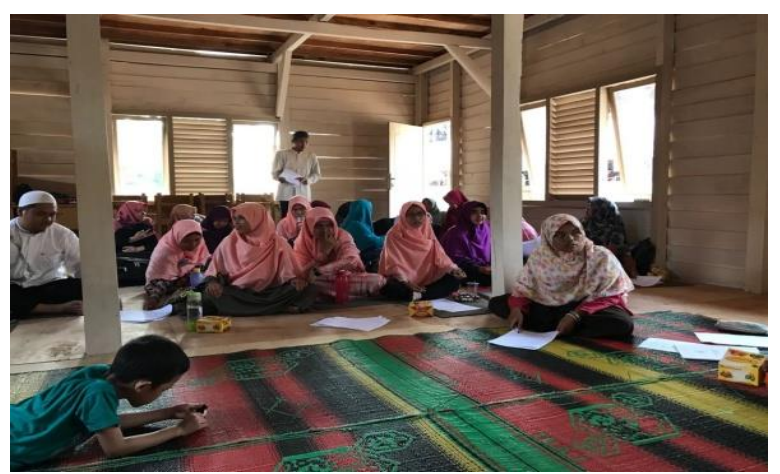

Gambar 4. Para guru di SD Alam Al-Fath antusias dalam mengikuti kegiatan pelatihan pada materi Geometri.

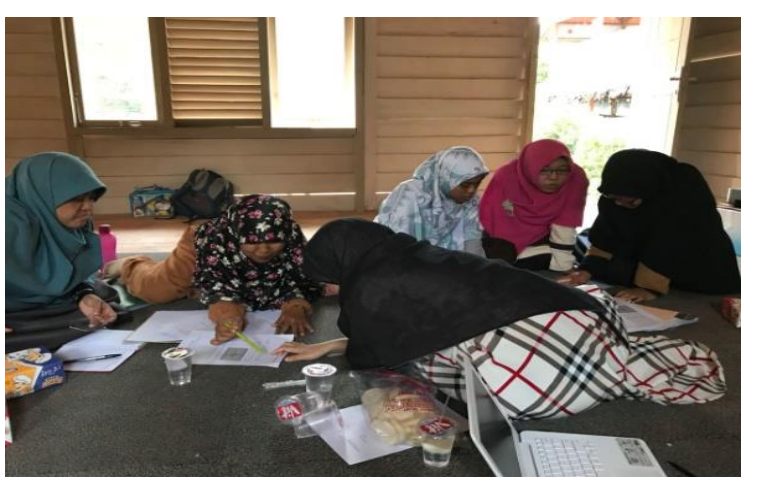

Gambar 5. Pemateri sedang membantu peserta menyelesaikan materi olimpiade.

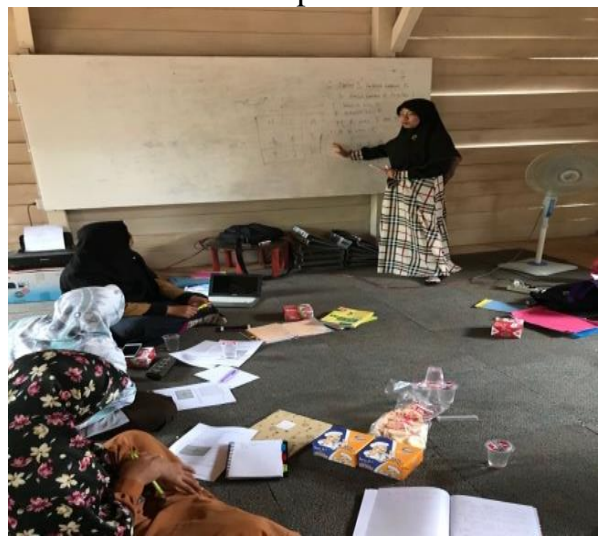

Gambar 6. Pemateri memaparkan materi bilangan pada soal olimpiade.

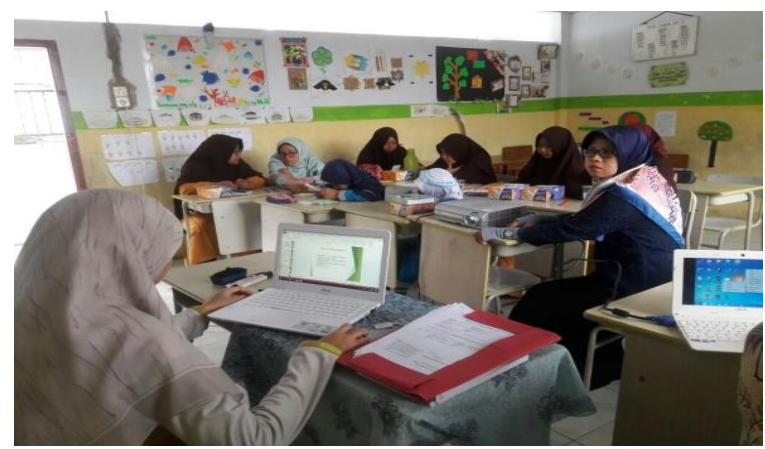

Gambar 7. Pemateri menjelaskan soal olimpiade pada materi aljabar. 


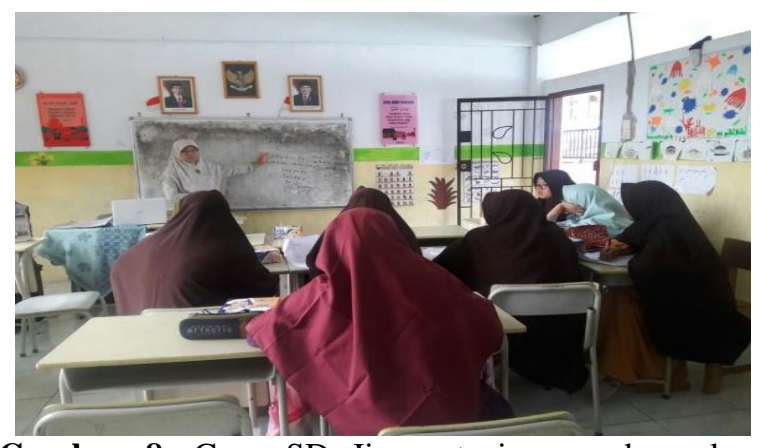

Gambar 8. Guru SD Jisc antusias mendengarkan pemaparan materi dari tim pengabdian.

\section{d. Uji Coba / Simulasi Pembahasan Soal-Soal Olimpiade Matematika SD}

Dari hasil simulasi penyelesaian soal-soal olimpiade yang diberikan, menunjukkan sebagian besar guru belum terbiasa mengerjakan soal olimpiade. Hal ini karena soal olimpiade tidak mudah dan mungkin penghargaan (reward) kepada guru dan siswa yang menekuni soal-saol matematika dan soal olimpiade masih kurang. Selain itu, guru juga masih terbiasa mengerjakan soal-soal standar yang ada dibuku siswa dan buku guru yang memang berbeda karakteristiknya dengan jenis soal olimpiade matematika.

Kegiatan pelaksanaan pengabdian telah dilaksanakan sebanyak 5 kali pertemuan untuk masing-masing sekolah yaitu SD Alam Al-Fath dan SD Jambi Islamic School (JISc). Dimana masing-masing sekolah melibatkan 10 orang guru dan 20 orang siswa. Guru terlibat aktif dalama membahas tipe soal PISA dan olimpiade. Gambar di bawah ini menunjukkan kegiatan guru mensosialisasikan pelaksanaan ujicoba/simulasi menyelesaikan soal olimpiade.

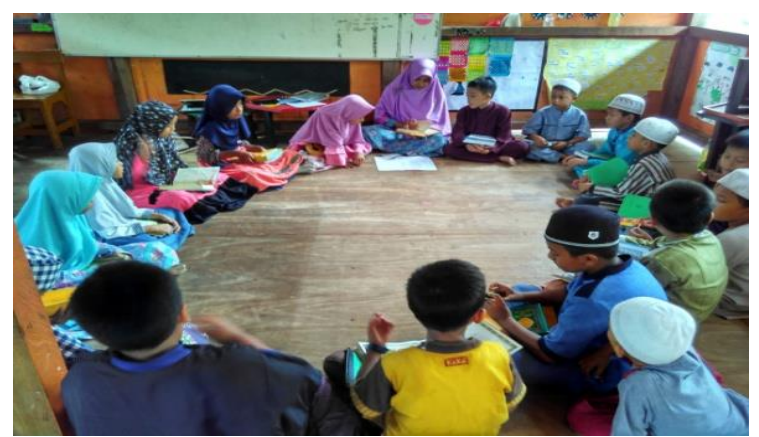

Gambar 9. Guru mensosialisasikan pelaksanaan simulasi penyelesaian soal olimpiade kepada para siswa.

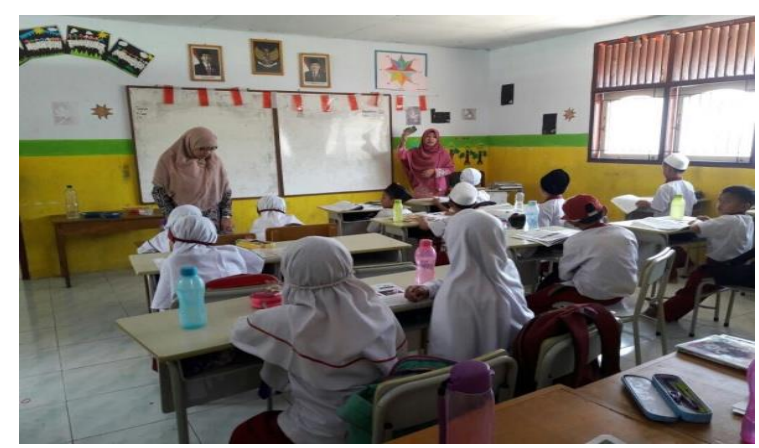

Gambar 10. Para siswa antusias mengikuti penyelesaian soal olimpiade.

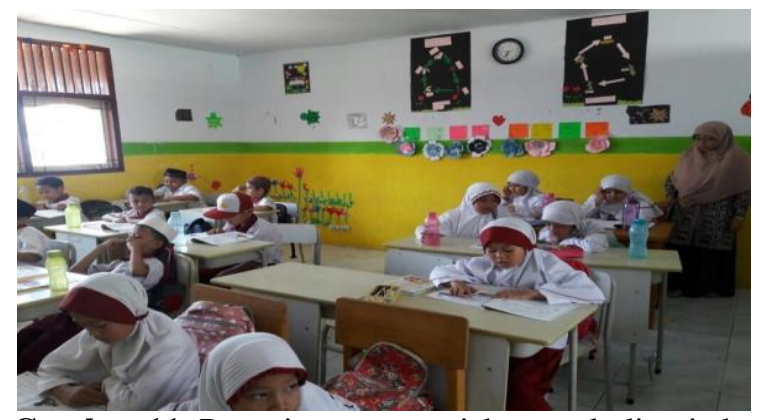

Gambar 11. Para siswa mengerjakan soal olimpiade.

Berikut akan disajikan sampel jawaban siswa dalam menyelesaikan soal olimpiade yang disusun oleh tim pada saat simulasi yaitu sebagai berikut:

1. Soal isian

"The diagonal of a trapezoid (trapesium sama kaki) is $10 \mathrm{~cm}$. The diagonal and the bottom of the trapezoid form a $45^{0}$ angle. The area of the trapezoid is ... $\mathrm{cm}^{2}$ ".

Jawaban dari siswa berikut benar tetapi membutuhkan waktu yang lama untuk menganalisa gambar.

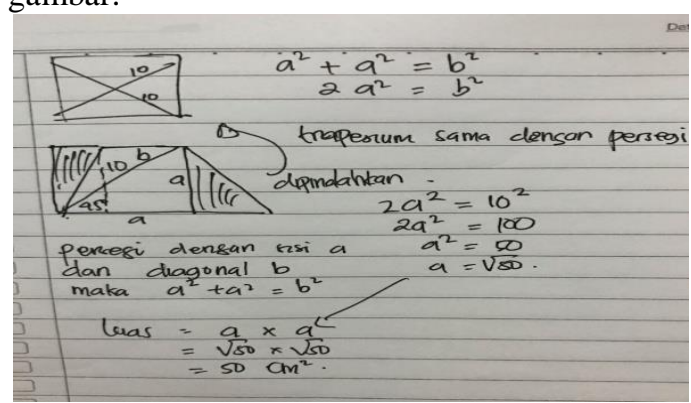

Gambar 12. Jawaban siswa pada soal isian.

2. Soal Uraian

"Untuk mengurangi abrasi pantai suatu pulau, sekelompok remaja menanam pohon mangrove dalam satu baris di sepanjang pantai sejauh 1,25 $\mathrm{km}$. Jarak antara dua mangrove dibuat sama. Jika jarak antara mangrove urutan ke-7 dan ke-23 adalah 32 meter, berapakah banyaknya pohn mangrove yang ditanam?"

Jawaban siswa berikut, jawabannya salah tetapi alurnya sudah mulai benar. Namun siswa melupakan rumus atau trik cepat. Sehingga hasil yang hampir benar menjadi salah. 


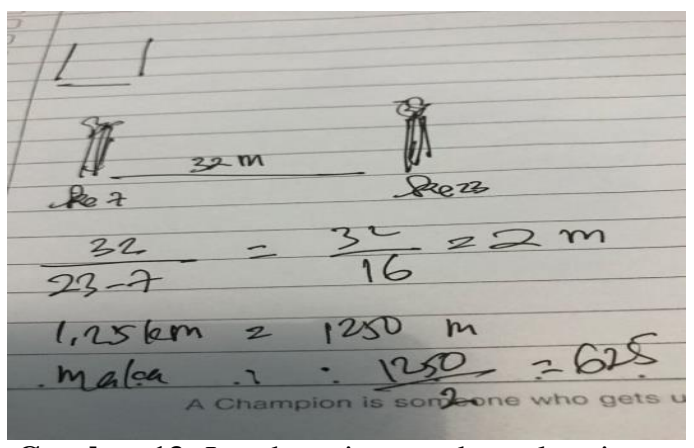

Gambar 13. Jawaban siswa pada soal uraian.

3. Soal eksplorasi

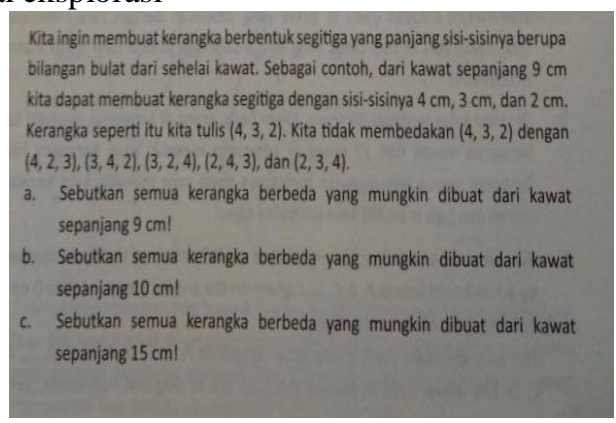

Gambar 14. Contoh Soal eksplorasi.

Pada soal eksplorasi ini, siswa masih banyak yang belum paham. Selain jarang diberikan guru dalam pemecahan kasus-kasus dalam kelas, siswa juga mengalami kesulitan dan membutuhkan waktu yang lama dalam mengerjakannya.

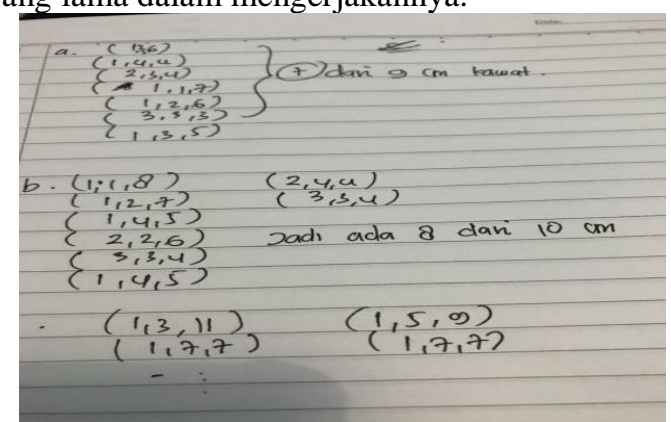

Gambar 15. Jawaban siswa pada soal eksplorasi.

Dari hasil jawaban siswa, rata-rata mereka memiliki kesulitan dalam mengerjakan soal geometri karena kebanyakan dari mereka lebih fokus untuk menggambar. Sedangkan untuk olimpiade jawaban benar sangat menentukan dan strategi yang digunakan siswa masih menghabiskan waktu yang banyak khususnya pada jenis soal eksplorasi.

\section{e. Evaluasi dan Refleksi}

Setelah kegiatan pelaksanaan pelatihan dilaksanakan dilakukan evaluasi untuk melihat sejauh mana kemampuan guru dalam mengikuti pelatihan dan melihat peningkatan hasil dari pre test ke post test. Soal yang diberikan berjumlah sama dengan pada saat pre test dan post test yang masing-masing soal berjumlah 5 buah untuk masing-masing tipe soal yaitu uraian, isian singkat dan eksplorasi. Hasil peningkatannya akan ditunjukkan pada diagram berikut:

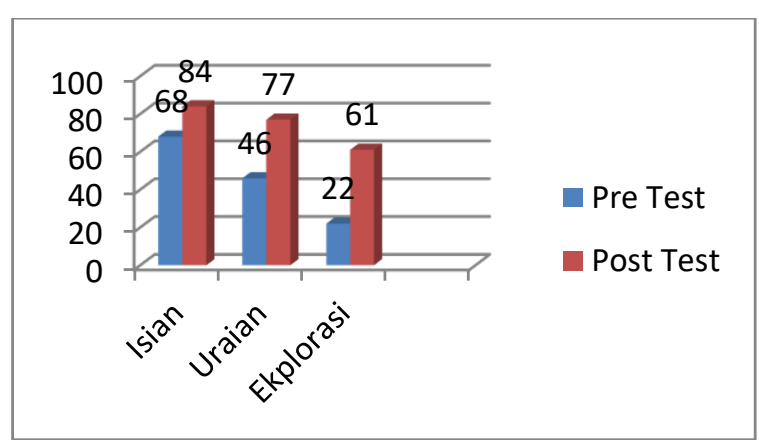

Diagram 1. Hasil Pretest dan Posttest berdasarkan tipe soal.

Berdasarkan hasil tersebut akan disajikan rata-rata hasil pemberian tes sebagai berikut:

\section{Rata-Rata hasil pemberian tes}

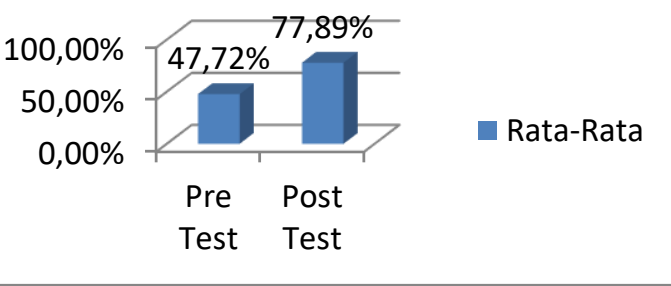

Diagram 2. Rata-rata Hasil Pre Test dan Post Test Dari hasil tersebut diperoleh peningkatan dari pre test ke post test sebesar $30,17 \%$.

Selain dengan adanya peningkatan hasil tes kemampuan guru dalam menjawab soal, evaluasi dengan pemberian angket respon juga disebar kepada para peserta pelatihan. Berikut disajikan hasil angket respon pengayaan materi soal olimpiade:

Tabel 2. Angket Respon Pengayaan Materi Olimpiade Matematika bagi Guru Sekolah Dasar.

\begin{tabular}{|c|c|c|c|c|}
\hline \multirow[t]{2}{*}{ No } & \multirow[t]{2}{*}{ Pernyataan } & \multicolumn{3}{|c|}{ Pilihan } \\
\hline & & SS & $\mathbf{S}$ & TS STS \\
\hline 1 & $\begin{array}{l}\text { Saya sangat antusias } \\
\text { mengikuti pengayaan dan } \\
\text { pelatihan Olimpiade } \\
\text { Matematika SD ini }\end{array}$ & 15 & 5 & \\
\hline 2 & $\begin{array}{l}\text { Untuk memahami konsep } \\
\text { matematika SD setingkat } \\
\text { olimpiade tidak } \\
\text { memerlukan pengayaan } \\
\text { dan pelatihan semacam } \\
\text { ini }\end{array}$ & & & 16 \\
\hline 3 & $\begin{array}{l}\text { Materi Pengayaan dan } \\
\text { Pelatihan sangat sulit } \\
\text { dipahami }\end{array}$ & & 4 & 16 \\
\hline 4 & $\begin{array}{l}\text { Penyampaian materi } \\
\text { pengayaan dan pelatihan } \\
\text { ini sangat menarik }\end{array}$ & 12 & 6 & 2 \\
\hline 5 & $\begin{array}{l}\text { Materi relevan dengan } \\
\text { objektifitas pelatihan }\end{array}$ & 15 & 5 & \\
\hline
\end{tabular}




\begin{tabular}{|c|c|c|c|c|c|}
\hline 6 & $\begin{array}{l}\text { Kenyamanan tempat yang } \\
\text { digunakan untuk } \\
\text { pelatihan ini cukup } \\
\text { memadai }\end{array}$ & 13 & 7 & & \\
\hline 7 & $\begin{array}{l}\text { Setelah mengikuti } \\
\text { pengayaan dan pelatihan } \\
\text { ini saya termotivasi untuk } \\
\text { membekali para siswa } \\
\text { dengan materi olimpiade } \\
\text { matematika SD }\end{array}$ & 16 & 4 & & \\
\hline 8 & $\begin{array}{l}\text { Pengayaan dan Pelatihan } \\
\text { olimpiade ini } \\
\text { membingungkan }\end{array}$ & & 2 & 10 & 8 \\
\hline 9 & $\begin{array}{l}\text { Waktu yang disediakan } \\
\text { untuk pengayaan dan } \\
\text { pelatihan ini sudah cukup } \\
\text { memadai }\end{array}$ & & 3 & 15 & 2 \\
\hline 10 & $\begin{array}{l}\text { Pemateri sangat } \\
\text { menguasai materi } \\
\text { pelatihan }\end{array}$ & 14 & 6 & & \\
\hline 11 & $\begin{array}{l}\text { Pengayaan dan Pelatihan } \\
\text { Olimpiade Matematika } \\
\text { SD ini sangat } \\
\text { membosankan (gaya } \\
\text { penyampaian) }\end{array}$ & & 1 & 16 & 3 \\
\hline 12 & $\begin{array}{l}\text { Pengayaan dan Pelatihan } \\
\text { semacam ini cukup } \\
\text { merepotkan saya }\end{array}$ & & & 12 & 8 \\
\hline 13 & $\begin{array}{l}\text { Jumlah pemateri cukup } \\
\text { memadai }\end{array}$ & 8 & 10 & 2 & \\
\hline 14 & $\begin{array}{l}\text { Pengayaan dan Pelatihan } \\
\text { Olimpiade Matematika } \\
\text { ini memberi inspirasi } \\
\text { saya untuk membekali } \\
\text { siswa siswi saya agar } \\
\text { mengikuti OSN }\end{array}$ & 8 & 12 & & \\
\hline 15 & $\begin{array}{l}\text { Saya selalu ingin } \\
\text { mencoba mengeksplorasi } \\
\text { soal-soal matematika } \\
\text { setaraf olimpiade }\end{array}$ & 8 & 11 & 1 & \\
\hline 16 & $\begin{array}{l}\text { Pengayaan dan Pelatihan } \\
\text { ini sangat rumit }\end{array}$ & & 3 & 16 & 1 \\
\hline 17 & $\begin{array}{l}\text { Fasilitas yang diberikan } \\
\text { dalam pelatihan ini } \\
\text { sangat memadai }\end{array}$ & 2 & 14 & 4 & \\
\hline 18 & $\begin{array}{l}\text { Pengelolaan waktu } \\
\text { pelatihan sangat baik }\end{array}$ & & 16 & 4 & \\
\hline 19 & $\begin{array}{l}\text { Pemateri dalam } \\
\text { memberikan materi } \\
\text { sangat baik }\end{array}$ & 6 & 13 & 1 & \\
\hline 20 & $\begin{array}{l}\text { Pelatihan ini pelu } \\
\text { ditindaklanjuti oleh setiap } \\
\text { peserta untuk } \\
\text { diimplementasikan dalam } \\
\text { pembelajaran matematika }\end{array}$ & 18 & 2 & & \\
\hline 21 & $\begin{array}{l}\text { Keberadaan pemateri } \\
\text { sangat membantu saya } \\
\text { dalam pelatihan ini }\end{array}$ & 3 & 15 & 2 & \\
\hline
\end{tabular}

\begin{tabular}{lllll}
\hline 22 & $\begin{array}{l}\text { Waktu yang dialokasikan } \\
\text { sudah cukup memadai } \\
\text { untuk menguasai materi }\end{array}$ & 6 & 10 & 4 \\
\hline 23 & $\begin{array}{l}\text { Saya merasa bosan dalam } \\
\text { mengikuti pelatihan ini }\end{array}$ & 1 & 19 & \\
\hline 24 & $\begin{array}{l}\text { Modul yang diberikan } \\
\text { mudah dipahami }\end{array}$ & 15 & 5 \\
\hline
\end{tabular}

Dari hasil angket tersebut, dapat disimpulkan bahwa secara umum para peserta merasa puas dengan pelatihan ini yang dapat dilihat dari pertanyaan positif mendapatkan hasil yang positif juga dari peserta, selain itu para guru juga terinspirasi sekaligus termotivasi untuk memberi pembekalan kepada siswa siswinya agar dapat mengikuti olimpiade matematika baik lokal maupun nasional. Namun masih banyakmateri-materi olimpiade yang tidak tercakup dalam pelatihan ini karena waktu yang bisa dimanfaatkan hanya terbatas berdasarkan kesibukan para guru dalam menyiapkan siswa-siswi untuk mengikuti ujian akhir semester dan Ujian Nasional. Dari hasil juga diperoleh materi geometri merupakan materi yang paling sulit dirasakan oleh guru dan siswa. Soal-soal yang sering dimunculkan lebih cenderung bersifat tricky.Untuk dapat menyelesaikan soal-soal olimpiade matematika, lebih diperlukan ide matematika yang kreatif daripada kemampuan dan kecepatan komputasi.Selain itu ciri utama dari soal olimpiade matematika adalah bersifat non-rutin dan menekankan pada pemecahan masalah (problem solving). Oleh karena itu, soal-soal olimpiade matematika jarang ditemui didalam kelas.

\section{3) Tindak Lanjut}

Berdasarkan evaluasi dan refleksi yang dikemukakan perlu dilakukan tindak lanjut pada masa yang akan datang, di antaranya sebagai berikut:

a. Pendampingan berkelanjutan tentang pengayaan dan pendalaman materi olimpiade lebih ditingkatkan dan disesuaikan dengan kelemahan yang paling menonjol yang ditemukan saat pelaksanaan kegiatan.

b. Pendampingan berkelanjutan tentang Pengayaan Materi Olimpiade Matematika sehingga dengan adanya kegiatan berlanjut motivasi guru dan siswa semakin baik dan antusias dalam mengikuti kegiatan olimpiade.

\subsection{Pembahasan}

Program pengabdian berupa pelatihan pengayaan materi olimpiade matematika di SD Alam Al-Fath dan SD Jambi Islamic School (JISc) telah berhasil dilaksanakan.Hal ini dapat dilihat berdasarkan catatan harian serta wawancara yang dilakukan selama guru memperoleh kegiatan tersebut menunjukkan sikap yang sangat antusias.Para guru jugatelah mampu menggunakan strategi penyelesaian soal olimpiade dan memberikan ujicoba kepada para siswa untuk menjawab dan membimbing soal-soal olimpiade. Selain itu, dijelaskan juga bahwa keberhasilan program ditandai dengan persentase keberhasilan $\geq 75 \%$ dengan kategori baik. 


\section{KESIMPULAN}

Pengayaan materi olimpiade matematika kepada guruguru SD memberikan hasil yang memuaskan berdasarkan hasil pemberian tes pretest ke postes yang mengalami peningkatan dan angket respon. Persentase peningkatan yang diperoleh yaitu sebesar 30,17\% dan hasil respon di setiap item pernyataan positif mayoritas memberikan jawaban setuju dan sangat setuju. Hal ini memberikan arti bahwa, dengan adanya kegiatan ini memberikan dampak yang positif kepada guru-guru untuk meningkatkan kemampuan dalam memahami dan menyelesaikan soal-soal olimpiade.

Selain hasil yang diperoleh di atas, tim pelaksana juga memberikan modul pengayaan soal olimpiade yang diserahkan ke kedua sekolah. Berikut sampul depan dari modul yang telah disusun oleh tim:

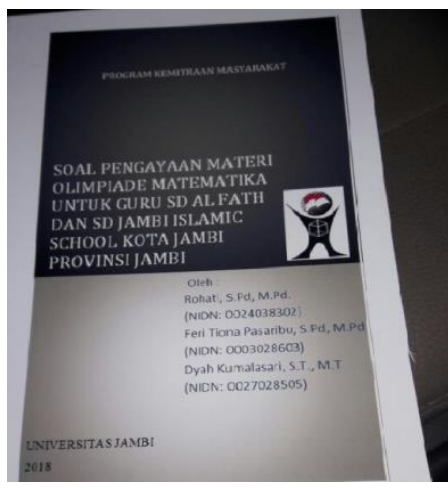

Gambar 16. Sampul modul pengayaan materi olimpiade matematika SD.

Modul ini digunakan selama kegiatan dan ditambah dengan buku penunjang yang relevan. Selain kepada guru-guru, kegiatan ini juga melibatkan orang tua siswa, siswa, kepala sekolah yang akan menjembatani setiap kegiatan olimpiade baik melalui dinas pendidikan kota maupun nasional. Kegiatan ini tetap dilakukan pendampingan berkelanjutan setelah kegiatan selesai demi tujuan semakin besar antusiasme siswa untuk mengikuti ajang olimpiade dan semangat guru dan pihak sekolah untuk terus memotivasi siswa meningkatkan kemampuannya dalam menyelesaikan soal-soal olimpiade. Selain itu kegiatan pengayaan olimpiade matematika ini memberikan efek positif bagi guru di sekolah dan diharapkan bisa semakin masif dilaksanakan di sekolah-sekolah yang lain di Provinsi Jambi.

\section{UCAPAN TERIMAKASIH}

Penulis mengucapkan terima kasih yang sebesarbesarny kepada Kemenristek Dikti yang sudah memberikan bantuan dana melalui skim Pengabdian Kemitraan Masyarakat (PKM) tahun anggaran 2018 dan Lembaga Penelitian dan Pengabdian Masyarakat (LPPM) Universitas Jambi.

\section{DAFTAR PUSTAKA}

Jana, P. (2017). Pembinaan Olimpiade Matematika kelas VA CI SD Negeri Ungaran I Yogyakarta . J-Dinamika, 2(2), 187-194.

Kusuma, J. (2010). Pembinaan Olimpiade Matematika. Jurnal Matematika, Statistika \& Komputasi. 6(2), 86-91.

Kuswidi, I \& Hart, E. (2017). Top Juara Olimpiade Sains Nasional (OSN) Matematika SD/MI, Tingkat Kabupaten/Kota Provinsi, dan Nasional. (p. 5). Laksana : Yogyakarta.

Mairing, J.P., Budayasa, I.K., Juniarti, D. (2011). Profil Pemecahan Masalah Siswa Peraih Medali OSN Matematika. Jurnal Pendidikan dan Pembelajaran. 18(1), 65-71.

Makur, A.P., Indra, R.C., Gunur, B. (2018). Kemampuan Berpikir Tingkat Tinggi, Peserta OSK Matematika Tingkat SD, dan Strategi Think, Talk and Write. Jurnal Pendidikan Matematika. 12(2), 23-32.

Mardiyana, dkk. (2016). Pada Seminar Matematika dan Pendidikan Matematika ( hal 848-860).

Rohim, M.F. dan Sari, A.F. ( 2019). Keterampilan Siswa Memecahkan Masalah Olimpiade Matematika Ditinjau dari Kepribadian Tipe Senising dan Intuiting. Jurnal Elemen. 5(1), 80-92.

Suarsana, I, M. (2017). Pendidikan dan Latihan Pembelajaran Pecahan Bagi Guru-guru Sekolah Dasar Gugus V Kecamatan Kubu. Jurnal Widya Laksana. 6(1), 52-61.

Suryawan, P. P., Gita, I. N., \& Hartawan, I.Y. (2017). Peningkatan Kompetensi Siswa Berbakat dalam Bidang Olimpiade Matematika Tingkat SD. Jurnal Widya Laksana. . 6(2), 100-112.

Trisnowali, A. (2015). Profil Disposisi Matematis Siswa Pemenang Olimpiade pada Tingkat Provinsi Sulawesi Selatan. Jurnal of EST, 1(3), 47-57.

Wibowo, S.S. (2015). Kumpulan Soal \& Pembahasan Olimpiade Matematika SD (p. xi). Yrama Widya: Bandung. 